\title{
Sikap Wanita Usia Subur Terhadap Keputihan di lingkungan VIII Kelurahan Wek V Padangsidimpuan Selatan
}

\begin{abstract}
Penulis:
Elpiana Sari ${ }^{1}$

Desi Meliana Gultom ${ }^{2}$

Afiliasi:

Institut Teknologi dan

Kesehatan Sumatera

Utara $^{1,2}$

Korespondensi:

elpianasari10@gmail.c

om

Histori Naskah:

Diajukan: 99-00-9999

Disetujui: 99-00-9999

Publikasi: 99-00-9999

Abstrak:

Keputihan atau flour albus adalah cairan berwarna putih agak kental melalui kemaluan wanita. Selain mengeluarkan cairan putih, wanita itu juga mengeluh gatal di kemaluan, nyeri bersetubuh, dan kemudian berbau tidak sedap. Penelitian ini bertujuan untuk mengidentifikasi Sikap Wanita Usia Subur Terhadap Keputihan Di Lingkungan VIII Kelurahan Wek V Kecamatan Padangsidimpuan Selatan. Penelitian ini bersifat metode deskriftip analitik dengan jumlah populasi 108 orang dengan sampel 27 responden. Cara pengumpulan data menggunakan kuisioner untuk memperoleh data, kemudian diolah dan dianalisa dengan cara editing, cording, scoring, transferring, tabulating. Hasil analisa disajikan dalam table distribusi frekuensi dan persentase. Dari 27 responden yang diteliti, mayoritas sikap merespon 10 orang (37\%). Pada kategori umur, mayoritas sikap menghargai 7 orang $(25,9 \%)$. Pada kategori pendidikan SMA, mayoritas sikap menghargai 5 orang (18,5\%). Pada kategori pekerjaan wiraswasta mayoritas sikap menghargai 5 orang. Dan pada kategori sumber informasi media elektronik mayoritas sikap menghargai 5 orang $(18,5)$. Peneliti mengharapkan kepada responden supaya menjaga sikap, tindakan dan lebih giat mengikuti penyuluhan serta mencari informasi dari sumber lain tentang Keputihan.
\end{abstract}

Kata kunci: Sikap, Wanita Usia Subur (WUS), Keputihan

\section{Pendahuluan}

Istilah wanita ditunjukkan untuk menyatakan seorang gadis yang telah mencapai usia dewasa dan matang secara emosi, afeksi serta telah memiliki kebebasan (Backer, 2016). Wanita dalam kesehatan menurut Notoatmodjo dan Ulfa (2016), yaitu ikut sertakan wanita sebagai anggota masyarakat dalam memecahkan masalah kesehatannya sendiri, dalam hal ini sendirilah yang aktif memikirkan, merencanakan, dan mengevaluasi program-program kesehatan masyakat.

Menurut data dari Departemen Kesehatan Republik Indonesia, wanita usia subur (WUS) adalah semua wanita yang telah memasuki usia antara 15-49 tahun. Perempuan yang ada di rentang usia ini masuk ke dalam kategori usia reproduktif baik itu belum menikah, janda ataupun sudah menikah (Depkes RI, 2016). Pada usia ini kesehatan reproduksi merupakan suatu keadaan sejahtera fisik, mental dan sosial secara utuh, tidak semata-mata bebas dari penyakit atau kecacatan dalam semua hal yang berkaitan dengan sistem reproduksi, serta fungsi, proses, dan peranan penting salah satunya dalam kesehatan reproduksi adalah perilaku kebersihan genetalia. Karena bila seseorang atau wanita terutama wanita usia subur (WUS) kurang menjaga kebersihan alat genetalia bisa menyebabkan terjadinya infeksi, yang dapat mengganggu pada fungsi reproduksinya (Intan, Iwan 2019). 
Pada diri seorang wanita di masa reproduksi biasanya mengalami beberapa gejala psikologik yang negatif atau gejala fisik. Sifat gejalanya bervariasi dan cenderung memburuk ketika saat menjelang dan selama terjadinya proses perdarahan haid pada tubuhnya, keadaan ini tidak selalu terjadi pada setiap siklus haidnya dan intensitasnya pun tidak sama. Beberapa wanita terutama wanita usia subur (WUS) ada juga yang mengalami gejala alam pearasaan dan fisik yang berat, salah satunya adalah menyebabkan terjadinya keputihan.

Keputihan atau flour albus merupakan kondisi vagina saat mengeluarkan cairan atau lendir menyerupai nanah (Hamid bahari, 2018). Keputihan mengeluarkan sekret atau cairan dari vagina selain darah haid seperti cairan berwarna putih agak kental melalui liang kemaluan wanita. Sekret terlalu banyak dan menimbulkan bau tidak enak disebabkan karena terjadinya peradangan dan infeksi pada liang vagina. Jika keputihan sudah berlangsung terus menerus akan mengganggu fungsi organ reproduksi wanita khususnya pada saluran indung telur yang dapat menyebabkan infertilitas, maka kemungkinan wanita yang bersangkutan akan menjadi mandul, dan kanker serviks yang berujung kematian (Wijanti,2015).

Di Indonesia sendiri sekitar 90\% wanita usia subur pernah mengalami keputihan. Hal tersebut berkaitan erat dengan kondisi cuaca yang lembab sehingga menyebabkan wanita di Indonesia mudah terkena keputihan. Karena pada kondisi inilah akan mudah terkena infeksi jamur. Keputihan yang terjadi tersebut cenderung disebabkan oleh masih minimnya kesadaran untuk menjaga kesehatan terutama kesehatan organ genetalianya (Ali, 2015).

Sedangkan di Provinsi Sumatera Utara yang mengalami keputihan sangat tinggi, dari laporan tersebut dapat di lihat bahwa wanita usia subur (WUS) lebih tinggi yang mengalami keputihan yaitu 8,5\% di bandingkan dengan ibu hamil yang hanya 5\% (Dinkes Prov.Sumut, 2016).

Berdasarkan hasil penelitian Hidayati (2015) menjelaskan bahwa keputihan dapat berhubungan dengan pekerjaan, jika dibandingkan dengan wanita pekerja ringan atau pekerja di kantor mempunyai resiko 4 kali lebih tinggi. Menurut Efendy Nasrul (2015) tingkat sosial ekonomi yang terlalu rendah akan dapat mempengaruhi individu menjadi tidak begitu memperhatikan kebersihan vagina karena lebih memikirkan banyak kebutuhan lain yang lebih mendesak. Maka dari sikap itu bisa dipastikan kurangnya rasa peduli terhadap kebersihan vagina yang akan menyebabkan keputihan.

Pendidikan juga menghambat sikap wanita usia subur terhadap keputihan yang mereka alami. Menurut Mubarak, (2015) semakin tinggi tingkat pendidikan seseorang, maka semakin mudah sesorang bisa menerima informasi sehingga semakin banyak pula menerima pengetahuan yang dimilikinya, dan tingkat pendidikan rendah maka dapat menghambat perkembangan perilaku sesorang terhadap kebersihan vagina.

Berdasarkan survey awal pendahuluan yang peneliti lakukan di Lingkungan VIII Kelurahan Wek V Kecamatan Padangsidimpuan Selatan Kota Padangsidimpuan, peneliti memperoleh data dari Kader Bidan Posyandu Lingkungan VIII bahwa jumlah wanita usia subur berjumlah 108 orang (populasi), dan dari hasil wawancara yang di lakukan pada 15 orang di dapatkan sikap wanita usia subur yang tidak peduli tentang keputihan dan 6 wanita usia subur yang menanggapi keputihan. Pengalaman yang saya temui dalam keluarga saya sendiri sangat terlihat tidak pedulinya terhadap vagina yang sudah terasa gatal, pedih dan panas. Ny. E sempat mengeluh rasa sakit yang dia alami tetapi belum berobat sampai 2 hari dibiarkan begitu saja yang ahirnya dinding vagina menjadi luka/kulit terkelupas seperti luka bakar, jadi dari sikap Ny. E kita jangan menyepelekan keputihan karena itu sangat berbahaya bila dibiarkan berlarut lama. 
Berdasarkan dari uraian diatas karena adanya wanita usia subur banyak yang mengalami keputihan dan tidak peduli tentang keputihan, maka penulis tertarik untuk meneliti tentang "Sikap Wanita Usia Subur Terhadap Keputihan di Lingkungan VIII Kelurahan Wek V Kecamatan Padangsidimpuan Selatan".

\section{Metode Penelitian}

Jenis penelitian yang digunakan adalah penelitian kuantitatif dengan desain deskriptif yaitu gambaran "Sikap Wanita Usia Subur Terhadap Keputihan di Lingkungan VIII Kelurahan Wek V Kecamatan Padangsidimpuan Selatan". Penelitian ini dilaksanakan di Lingkungan VIII Kelurahan WeK V Kecamatan Padangsidimpun Selatan. Populasi dalam penelitian ini adalah seluruh wanita usia subur di Lingkungan VIII Kelurahan Wek V Kecamatan Padangsidimpuan Selatan 1. Besar sampel adalah sebanyak 27 orang. Data yang dikumpulkan meliputi data primer dan data sekunder.

\section{Hasil}

\section{Data Umum}

Tabel Distribusi Frekuensi Sikap Wanita Usia Subur Terhadap Keputihan

\begin{tabular}{clcc} 
No. & \multicolumn{1}{c}{ Sikap } & Frekuensi & Persentase (\%) \\
\hline 1 & Menerima & 5 Orang & $18,6 \%$ \\
2 & Merespon & 10 Orang & $37 \%$ \\
3 & Menghargai & 9 Orang & $33,3 \%$ \\
4 & Bertanggung Jawab & 3 Orang & $11,1 \%$ \\
\hline \multicolumn{2}{c}{ Jumlah } & 27 Orang & $\mathbf{1 0 0 \%}$ \\
\hline
\end{tabular}

Berdasarkan tabel diatas dapat dilihat bahwa distribusi frekuensi Sikap Wanita Usia Subur Terhadap Keputihan, responden dengan sikap menerima 5 orang $(18,6 \%)$, merespon 10 orang (37\%), menghargai 9 orang $(33,3 \%)$ dan bertanggung jawab 3 orang $(11,1 \%)$

\begin{tabular}{cccc}
\multicolumn{4}{c}{ Tabel Distribusi Frekuensi Karekteristik Responden Berdasarkan Umur } \\
\hline No. & Umur & Frekuensi & Persentase $(\%)$ \\
\hline 1 & 15-31 Tahun & 16 Orang & $59,2 \%$ \\
2 & $32-49$ Tahun & 11 Orang & $40,8 \%$ \\
\hline & Total & 27 Orang & $\mathbf{1 0 0 \%}$ \\
\hline
\end{tabular}

Berdasarkan tabel diatas dapat dilihat bahwa distribusi frekuensi responden yang berumur 15-31 tahun 16 orang $(59,2 \%)$, dan responden yang berumur 32-49 tahun 11 orang $(40,8 \%)$.

Tabel Distribusi Frekuensi Karekteristik Responden Berdasarkan Pendidikan

\begin{tabular}{clcc}
\hline No & Pendidikan & Frekuensi & Persentase (\%) \\
\hline 1. & SD & 3 Orang & $11,1 \%$ \\
2. & SMP & 5 Orang & $18,5 \%$ \\
3. & SMA & 11 Orang & $40,8 \%$
\end{tabular}




\begin{tabular}{|c|c|c|c|}
\hline 4. & Perguruan Tinggi & 8 Orang & $29,6 \%$ \\
\hline & Jumlah & 27 Orang & $100 \%$ \\
\hline
\end{tabular}

Berdasarkan tabel diatas dapat dilihat bahwa distribusi frekuensi responden yang berpendidikan tingkat SD berjumlah 3orang $(11,1 \%)$, yang berpendidikan tingkat SMP berjumlah 5 orang $(18,5 \%)$, yang berpendidikan tingkat SMA berjumlah 11 orang $(40,8 \%)$, dan yang berpendidikan tingkat Perguruan Tinggi berjumlah 8orang (29,6\%).

Tabel Distribusi Frekuensi Karekteristik Responden Berdasarkan Pekerjaan

\begin{tabular}{clcc}
\hline No & \multicolumn{1}{c}{ Pekerjaan } & Frekuensi & Persentase (\%) \\
\hline 1. & PNS & 3 Orang & $11,1 \%$ \\
2. & Wiraswasta & 12 Orang & $44,5 \%$ \\
3. & Petani & 2 Orang & $7,4 \%$ \\
4. & IRT & 10 Orang & $37 \%$ \\
\hline \multicolumn{2}{r}{ Jumlah } & 27 Orang & $\mathbf{1 0 0 \%}$ \\
\hline
\end{tabular}

Berdasarkan tabel diatas dapat dilihat bahwa distribusi frekuensi responden yang bekerja sebagai PNS sebanyak 3 orang $(11,1 \%)$, sebagai Petani sebanyak 2 orang $(7,4 \%)$, sebagai Wiraswasta 12orang (44,5\%), dan yang Tidak Bekerja/IRT 10 orang (37\%).

Tabel Distribusi Frekuensi Karekteristik Responden Berdasarkan Sumber Informasi

\begin{tabular}{llcc}
\hline No & Sumber Informasi & Frekuensi & Persentase (\%) \\
\hline 1. & Media Cetak & 9 Orang & $33,3 \%$ \\
2. & Media Elekronik & 11 Orang & $40,8 \%$ \\
3. & Media Kesehatan & 7 Orang & $25,9 \%$ \\
\hline & Jumlah & 27 Orang & $\mathbf{1 0 0 \%}$ \\
\hline
\end{tabular}

Berdasarkan tabel diatas dapat dilihat bahwa distribusi frekuensi responden memperoleh informasi dari Media Cetak 9orang (33,3\%), responden memperoleh informasi dari Media Elekronik 11 orang $(40,8 \%)$, dan responden memperoleh informasi dari Media Kesehatan sebanyak 7 orang $(25,9 \%)$.

\section{Data Khusus}

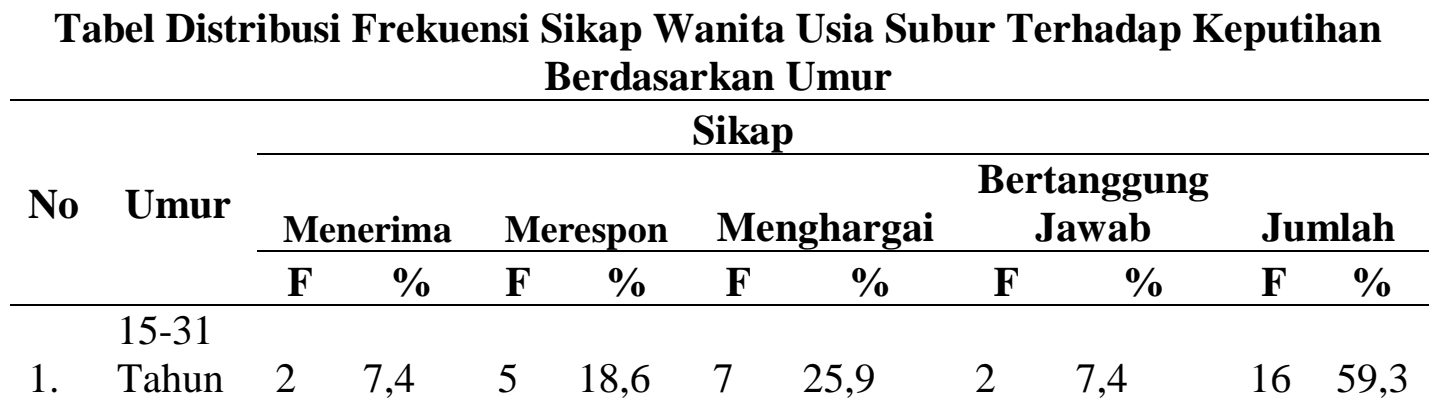


$32-49$

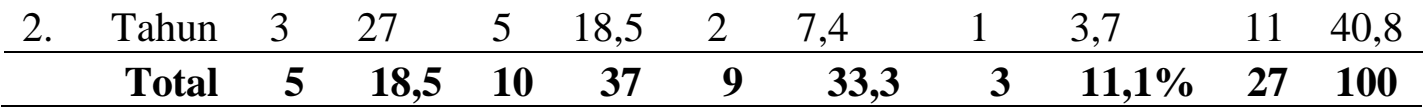

Berdasarkan tabel diatas dapat dilihat bahwa distribusi frekuensi karesteristik responden berdasarkan umur diperoleh dari 27 orang dengan umur 15-31 tahun 16 orang $(59,3 \%)$, sikap menerima 2 orang $(7,4 \%)$, merespon 5 orang $(18,5 \%)$, menghargai 7 orang $(25,9)$, dan bertanggung jawab 2 orang $(7,4 \%)$. Pada umur 32-49 tahun 11 orang $(40,8 \%)$, sikap menerima 3 orang $(11,1 \%)$, merespon 5 orang $(18,5 \%)$, mengharagai 2 orang $(7,4 \%)$, dan bertanggung jawab 1 orang $(3,7 \%)$.

\section{Tabel Distribusi Frekuensi Sikap Wanita Usia Subur Terhadap Keputihan Berdasarkan Pendidikan}

\begin{tabular}{|c|c|c|c|c|c|c|c|c|c|c|c|}
\hline \multirow{3}{*}{ No. } & \multirow{3}{*}{ Pendidikan } & \multicolumn{8}{|c|}{ Sikap } & & \\
\hline & & \multicolumn{2}{|c|}{ Menerima } & \multicolumn{2}{|c|}{ Merespon } & \multicolumn{2}{|c|}{ Menghargai } & \multicolumn{2}{|c|}{$\begin{array}{c}\text { Bertanggung } \\
\text { Jawab }\end{array}$} & \multicolumn{2}{|c|}{ Jumlah } \\
\hline & & $\mathbf{F}$ & $\%$ & $\mathbf{F}$ & $\%$ & $\mathbf{F}$ & $\%$ & $\mathbf{F}$ & $\%$ & $\mathbf{F}$ & $\%$ \\
\hline 1. & SD & 2 & 7,4 & 1 & 3,7 & - & - & - & - & 3 & 11,1 \\
\hline 2. & SMP & 3 & 11,1 & 2 & 7,4 & - & - & - & - & 5 & 18,5 \\
\hline 3. & SMA & - & - & 4 & 14,8 & 6 & 22,2 & 1 & 3,7 & 11 & 40,8 \\
\hline 4. & $\begin{array}{l}\text { Perguruan } \\
\text { Tinggi }\end{array}$ & - & - & 2 & 7,4 & 4 & 14,8 & 2 & 7,4 & 8 & 29,6 \\
\hline & Total & 5 & 18,5 & 9 & 33,3 & 9 & 33,3 & 3 & 11,1 & 27 & 100 \\
\hline
\end{tabular}

Berdasarkan tabel diatas dapat dilihat bahwa distribusi frekuensi karesteristik responden berdasarkan umurdiperoleh dari 27 orang dengan Pendidikan SD 3 orang $(11.1 \%)$, dengan sikap menerima 2 orang $(7,4 \%)$, merespon 1 orang $(3,7 \%)$. Pada kategori Pendidikan SMP 5 orang $(18,5 \%)$, sikap menerima 3 orang $(11,1 \%)$, merespon 2 orang $(7,4 \%)$. Pada kategori Pendidikan SMA 11 orang (40,7\%), sikap merespon 4 orang $(14,8)$, mengharagai 5 orang $(18,5 \%)$, dan bertanggung jawab 1 orang $(3,7 \%)$. Pada pendidikan Perguruan Tinggi 8 orang $(29,7 \%)$, sikap merespon 2 orang $(7,4)$, mengharagai 4 orang $(14,5 \%)$, dan bertanggung jawab 2 orang $(7,4 \%)$

Tabel Distribusi Frekuensi Sikap Wanita Usia Subur Terhadap Keputihan Berdasarkan Pekerjaan

\begin{tabular}{|c|c|c|c|c|c|c|c|c|c|c|c|}
\hline \multirow{3}{*}{ No. } & \multirow{3}{*}{ Pekerjaan } & \multicolumn{8}{|c|}{ Sikap } & & \\
\hline & & \multicolumn{2}{|c|}{ Menerima } & \multicolumn{2}{|c|}{ Merespon } & \multicolumn{2}{|c|}{ Menghargai } & \multicolumn{2}{|c|}{$\begin{array}{c}\text { Bertanggung } \\
\text { Jawab }\end{array}$} & \multicolumn{2}{|c|}{ Jumlah } \\
\hline & & $\mathbf{F}$ & $\%$ & $\mathbf{F}$ & $\%$ & $\mathbf{F}$ & $\%$ & $\mathbf{F}$ & $\%$ & $\mathbf{F}$ & $\%$ \\
\hline 1. & PNS & - & - & 1 & 3,7 & 2 & 7,4 & - & - & 3 & 11,1 \\
\hline 2. & Wiraswasta & - & - & 3 & 11,1 & 6 & 22,2 & 3 & 11,1 & 12 & 44,5 \\
\hline 3. & Petani & 1 & 3,7 & 1 & 3,7 & - & . & - & - & 2 & 7,4 \\
\hline
\end{tabular}




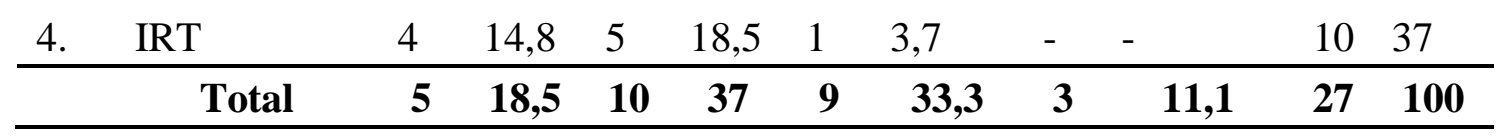

Berdasarkan tabel diatas dapat dilihat bahwa distribusi frekuensi karesteristik responden berdasarkan Pekerjaan diperoleh dari 27 orang dengan Pekerjaan PNS 3 orang $(11.1 \%)$, dengan sikap merespon 1 orang $(3,7 \%)$, dan menghargai 2 orang $(7,4 \%)$. Pada kategori Pekerjaan Wiraswasta 12 orang $(44,5 \%)$, sikap merespon 3 orang $(11,1 \%)$, menghargai 5 orang $(18,5 \%)$, dan bertanggung jawab 3 orang $(11,1 \%)$. Pada kategori pekerjaan Petani 2 orang $(7,4 \%)$, sikap menerima 1 orang $(3,7)$, merespon 1 orang $(3,7 \%)$. Pada IRT 10 orang $(37 \%)$, sikap menerima 4 orang $(14,8)$, merespon 5 orang $(18,5 \%)$, dan mengharagai 1 orang $(3,7 \%)$.

Tabel Distribusi Frekuensi Sikap Wanita Usia Subur Terhadap Keputihan Berdasarkan Sumber Informasi

\begin{tabular}{|c|c|c|c|c|c|c|c|c|c|c|c|}
\hline \multirow{3}{*}{ No. } & \multirow{3}{*}{$\begin{array}{l}\text { Sumber } \\
\text { Informasi }\end{array}$} & \multicolumn{8}{|c|}{ Sikap } & & \\
\hline & & \multicolumn{2}{|c|}{ Menerima } & \multicolumn{2}{|c|}{ Merespon } & \multicolumn{2}{|c|}{ Menghargai } & \multicolumn{2}{|c|}{$\begin{array}{c}\text { Bertanggung } \\
\text { Jawab }\end{array}$} & \multicolumn{2}{|c|}{ Jumlah } \\
\hline & & $\mathbf{F}$ & $\%$ & $\mathbf{F}$ & $\%$ & $\mathbf{F}$ & $\%$ & $\mathbf{F}$ & $\%$ & $\mathbf{F}$ & $\%$ \\
\hline 1 & M. Cetak & 2 & 7,4 & 4 & 14,8 & 2 & 7,4 & 1 & 3,7 & 9 & $\begin{array}{l}33, \\
3\end{array}$ \\
\hline 2 & M. Elektronik & 1 & 3,7 & 3 & 11,1 & 5 & 18,5 & 2 & 7,4 & 11 & $\begin{array}{l}40 \\
8\end{array}$ \\
\hline \multirow[t]{2}{*}{3} & M. Kesehatan & 2 & 7,4 & 3 & 11,1 & 2 & 7,4 & - & - & 7 & $\begin{array}{l}25 \\
9\end{array}$ \\
\hline & Total & 5 & 18,5 & 10 & 37 & 9 & 33,3 & 3 & 11,1 & 27 & 100 \\
\hline
\end{tabular}

Berdasarkan tabel diatas dapat dilihat bahwa distribusi frekuensi karesteristik responden berdasarkan sumberi nformasi diperoleh dari 27 orang dengan Sumber informasi menggunakan media cetak 9 orang $(33,3 \%)$, dengan sikap menerima 2 orang $(7,4)$ merespon 4 orang $(14,8 \%)$, menghargai 2 orang $(7,4 \%)$ dan bertanggung jawab 1 orang $(3,7 \%)$. Pada kategori Media elektronik 11 orang $(40,8 \%)$, sikap menerima 1 orang $(3,7 \%)$ merespon 3 orang $(11,1 \%)$, menghargai 5 orang $(18,5 \%)$, dan bertanggung jawab 2 orang $(7,4 \%)$. Pada kategori media kesehatan 2 orang $(7,4 \%)$, sikap menerima 2 orang $(7,4)$, merespon 3 orang $(11,1 \%)$, mengharagai 2 orang $(7,4 \%)$.

\section{Pembahasan}

Berdasarkan data hasil penelitian Sikap Wanita Usia Subur Terhadap Keputihan di Lingkungan VIII Kelurahan Wek V Kec. Padangsidimpuan Selatan, yang dipengaruhi oleh beberapa faktor yaitu umur, pendidikan, pekerjaan, sumber informasi. Yang disajikan dalam bentuk tabel pada lembar sebelumnya. 


\section{Sikap Wanita Usia Subur Terhadap Keputihan}

Gerungan, 2019 menyatakan bahwa sikap merupakan sikap pandangan atau sikap perasaan, tetapi sikap mana disertai oleh kecenderungan bertindak sesuai dengan sikap terhadap objek. Dari hasil penelitian diatas, peneliti beramsumsi bahwa sikap wanita usia subur tehadap keputihan bertolak belakang. Ini dapat dilihat dari 27 responden yang mempunyai sikap merespon sebanyak 10 orang. Hal ini disebabkan kurangnya menjaga kebersihan vagina dan pandangan responden tentang keputihan serta kurangnya tindakan, pengalaman sehingga tidak mempedulikan keputihan yang dialaminya. Pada dasarnya ada beberapa faktor yang mempengaruhi sikap responden yaitu umur, pendidikan, pekerjaan, dan sumber informasi.

\section{Umur}

Menurut Huclok (2015) semakin cukup umur, tingkat kematangan dan kekuatan seseorang akan lebih matang dalam berpikir dan bekerja. Asumsi teori diatas bertolak belakang dengan hasil penelitian yang dilakukan peneliti, kareana di umur 15-31 tahun lebih banyak mengerti tentang keputihan walaupun di umur 32-49 tahun lebih berpengalaman tetapi tindakan/sikap responden umur 15-31 lebih tinggi sikapnya dibanding responden yang berumur 32-49 tahun. Hal ini dikarenakan usia 32-49 tahun sudah mulai mengabaikan tentang keputihan karna beranggapan tidak bermasalah pada kesehatan.

\section{Pendidikan}

Menurut Mantra dan Wawan dan Dewi (2016), pendidikan dapat mempengaruhi seseorang termasuk juga perilaku seseorang akan pola hidup terutama dalam memotivasi untuk sikap dalam pembangunan. Semakin tinggi pendidikan maka semakin mudah menerima informasi. Asumsi dari hasil penelitian ini sesuai dengan teori makin tinggi pendidikan seseorang makin baik sikap/perilaku dan makin mudah menerima informasi dengan bertambahnya pendidikan, tetapi walaupun pendidikan SMA belum terlalu tinggi sudah lumayan banyak paham tentang keputihan bahkan responden sering mendengar cara mencegah keputihan dari petugas kesehatan saat promosi disekolahnya.

\section{Pekerjaan}

Menurut Notoadmodjo (2016), pekerjaan adalah keburukan yang harus dilakukan terutama untuk menunjang kehidupannya dan kehidupan keluarga. Pekerjaan bukanlah sumber kesenangan, tetapi lebih baik merupakan cara mencari nafkah yang membosankan, berulang dan banyak tantangan. Sedangkan bekerja umumnya merupakan kegiatan yang menyita waktu. Bekerja bagi ibu-ibu akan mempunyai pengaruh terhadap kehidupan keluarga. Asumsi dari hasil penelitian sesuai dengan teori, penelitian ini disimpulkan bahwa responden yang bekerja sebagai wiraswasta lebih banyak wawasan/komunikasi juga sikapnya lebih baik dibangdingkan petani hal ini dikarenakan jarang berkumpul dan berkomunikasi dengan orang lain sehingga responden kurang mendapatkan informasi tentang keputihan.

\section{Sumber Informasi}

Menurut Mubarok (2016) sumber informasi merupakan kemudahan untuk memperoleh suatu informasi yang mempercepat seseorang memperoleh pengetahuan yang baru. Alat atau sasaran untuk menyampaikan informasi, guna menambah wawasan dan pengetahuan yang berpengaruh pada sikap seseorang, yang dimaksud dengan informasi komunikasi yang diajukan 
kepada orang ramai diluar organisasai itu ada macam-macam seperti media cetak, media elektronik, dan petugas kesehatan.

Asumsi dari hasil penelitian ini sesuai dari teori diatas, wanita usia subur menerima sumber informasi diperoleh media cetak, media elektronik, dan media kesehatan. Dari hasil penelitian dapat disimpulkan bahwa sumber informasi mayoritas wanita usia subur mendapatkan informasi lebih banyak dari media elektronik dibandingkan dari petugas kesehatan. Hal ini disebabkan bahwa sumber informasi dapat diterima dari mana saja. Tetapi lebih baiknya informasi kesehatan dapat diterima dari petugas kesehatan secara langsung/promosi kesehatan seperti leaflat, wawancara, tanya jawab, praktek langsung, karena kebanyakan orang lebih mengerti atau paham secara langsung dari pada hanya dilihat tapi tidak perna dipraktekkan.

\section{Kesimpulan}

Sikap Wanita Usia Subur Terhadap Keputihan Di Lingkungan VIII Kelurahan Wek V Kec. Padangsidimpuan Selatan, mayoritas sikap merespon sebanyak 10 orang (37\%), dan minoritas sikap bertanggung jawab sebanyak 3 orang $(11,1 \%)$. Berdasarkan Umur, mayoritas pada umur 1531 tahun sebanyak 16 orang $(59,2 \%)$, dengan kategori sikap menghargai 7 orang $(25,9 \%)$, dan minoritas pada umur 32-49 tahun 11 orang(40,8\%), dengan kategori sikap bertyanggung jawab 1 orang $(3,7 \%)$. Berdasarkan Pendidikan, manyoritas pendidikan SMA 11 orang $(40,8 \%)$, dengan kategori sikap mengargai 5 orang $(18,5 \%)$, dan minoritas pendidikan SD sebanyak 3 orang $(11,1 \%)$, dengan kategori sikap meresponm 1 orang $(3,7 \%)$. Berdasarkan Pekerjaan, mayoritas bekerja Wiraswasta 12 orang $(44,5 \%)$, dengan kategori sikap menghargai 6 orang $(22,2 \%)$, dan minoritas bekerja petani 2 orang (7,4\%), dengan kategori sikap merespon 1 orang (3,7). Sikap Wanita Usia Subur Berdasarkan Sumber Informasi, mayoritasdari Media Elektronik 11 orang (40,8\%), dengan kategori sikap menghargai 5 orang (18,5\%), dan minoritas Media Kesehatan 7 orang $(29,6 \%)$, dengan sikap menghargai 2 orang $(7,4 \%)$.

\section{Ucapan Terima Kasih}

Terimakasih kepada seluruh pihak yang telah membantu dalam penelitian ini.

\section{Referensi}

A.Wawan \& Dewi M., 2019. Buku ajar Teori \& Pengukuran Pengetahuan, Sikap, Dan Peilaku Manusia. Yogyakarta : Nuha Mediaka.

Andiasti Ajani, 2019. https://glizmedia.co/post.relationship/pregnancy/wanita-usia-subur. Diakses pada tanggal 28 November 2019.

Bramantyo, Enni Hanifa, 2017. Solusi Problem Wanita Dewasa. Jakarta : Puspa Swara.

D Paramitha, 2018. Repository.poltekkes-denpasar.ac.id. Diakses pada tanggal 28 November 2019.

GA Marhaeni, 2016. http://ejournal.poltekkes.denpasar.ac.id. Diakses pada tanggal 14 februari 2020.

Hamid Bahari, 2018. Buku ajar Cara Mudah Atasi Keputihan. Jogyakarta : Buku Biru. 


\section{Health Caring: Jurnal Illmiah Kesehatan}

Volume : 1 | Nomor 1 | Januari 2022 | E-ISSN : 2809-9117

Intan Kumalasari APP, Iwan Andhyantoro, S.K.M., 2019. Buku ajar Kesehatan Reproduksi. Jakarta : Salemba Medika.

Prof. Dr. Soekidjo Notoatmodjo, 2010. Buku ajar Metodologi Penelitian Kesehatan. Jakarta : Rineka Cipta.

Pedoman Penyusanan dan Penulisan Karya Tulis Ilmiah (KTI), 2019. STIKes Syuhada : Padangsidimpuan.

S Ayu, 2018. Repository.poltekkes-denpasar.ac.id. Diakses pada tanggal 28 November 2019.

Shadine, Mahannad, Enni Hanifa, 2015. Penyakit Wanita. Jogjakarta : Cipta Pustaka

SoburSetiaman,2019.http://www.academia.edu/37920383/MERANCANG_KUESIONER_UNTU K_PENELITIAN. Diakses pada tanggal 27 Februari 2020.

Sunaryo, 2015. Faktor yang Pempengaruhi Pembentukan dan Perubahan Sikap. Di kutip dari Enni Hanifa.

Th. Endang Purwoastuti, S. Pd, APP, Elisabeth Siwi Walyani, Amd, 2015. Keb. Buku ajar Ilmu Kesehatan Masyarakat dalam Kebidanan. Yogyakarta : PUSTAKABARUPRESS. 